Islam, English medium instruction in the private universities in Bangladesh

\title{
ENGLISH MEDIUM INSTRUCTION IN THE PRIVATE UNIVERSITIES IN BANGLADESH
}

\author{
M. Monjurul Islam \\ International University of Business Agriculture and Technology, Bangladesh \\ e-mail : monj0603@gmail.com
}

\begin{abstract}
As it is viewed English Medium Instruction (EMI) at tertiary level has emerged as a big educational issue in Bangladesh as well as many parts of the world. Hence, the present trend of Bangladeshi higher education has assessed some crucial reasons of the extended use of English as a medium of instruction. Although education researchers in other countries have worked in this area to understand this educational issue, there has been very little research on EMI at tertiary level in Bangladesh. That is why, this study reports a case study involving teachers and students in a private university in Bangladesh by critically examining the language practice and implementation of EMI policy within the context of Bangladeshi higher education. Based on the analysis of interview data, it is argued that through their language practices and beliefs students and teachers constructed their perception towards the accomplishment of EMI policy, educational choice and effectiveness of EMI policy. It is suggested that implications of MOI policies world-wide and the national level practices of students' content knowledge and English proficiency development in a globalizing world where English is widely believed to hold mammoth prospective for individuals and societies because of its role in human capital development.
\end{abstract}

Keywords: English; medium of instruction; language policy; higher education.

\section{PENGGUNAAN BAHASA INGGRIS SEBAGAI BAHASA PENGANTAR PADA UNIVERSITAS SWASTA DI BANGLADESH}

\begin{abstract}
Abstrak: Seperti yang bisa diamati, pembelajaran bermedium bahasa Inggris (English Medium Instruction (EMI) di jenjang perguruan tinggi telah menjadi masalah pendidikan yang besar di Bangladesh juga dan di berbagai belahan dunia lainnya. Karena itu, kecenderungan terkini pendidikan tinggi di Bangladesh telah menimbang beberapa alasan penting mengenai perpanjangan penggunaan bahasa Inggris sebagai medium pembelajaran. Meskipun para peneliti pendidikan di negara-negara lain telah bekerja di bidang ini untuk memahami masalah pendidikan ini, namun hanya ada sedikit sekali penelitian EMI di tingkat pendidikan tinggi yang dilakukan di Bangladesh. Itulah sebabnya, kajian ini melaporkan sebuah studi kasus yang melibatkan para guru dan siswa di sebuah universitas swasta di Bangladesh dengan secara kritis meneliti praktik bahasa dan penerapan kebijakan EMI, pilihan pendidikan dan manfaat kebijakan EMI.
\end{abstract}

Katakunci: bahasa Inggris, media pembelajaran, kebijakan bahasa, pendidikan tinggi. 
The existing flow of adopting English Medium Instruction (EMI) defined as the vehicle of teaching and learning has become an important issue in the language policy and planning. From a chronological point of view, medium of instruction (MOI) (factually English) has matched up to different phases of modernity from colonial period to post-modern. The early colonial period can be situated in European colonial systems in Asia and Africa. Although the role of colonized communities in advancing or resisting Western education through colonial languages cannot be underestimated (Pennycook, 1994, 1998), the colonial MOI can be described as a political imposition upon the natives aimed at facilitating and lengthening colonial rule (Hamid, 2009a). Far from being universal, education through colonial languages was elitist and targeted only the upper divisions of the populace. The second period of MOI followed the official end of colonial rule and prioritized national languages as an expression of national identity and aspirations. This MOI marked post-colonial reactions to colonial education and language policies. The third period, which we are currently in, can be called "appropriated MOI" which has seen the return of English, the colonial language now as a global language as a result of the local reappraisal of language-based nationalism, the sociolinguistic reality of English in a globalizing world, and the discourses of English in the context of human capital development and national participation in a global economy (Lin \& Martin, 2005; Rassool, 2007; Tsui \& Tellefson, 2007).

The above broad-brush overview of the global evolution of English Medium Instruction (EMI), although helpful, may not be observed in distinct, sequential phases in a particular polity or region (e.g., Europe). In fact, EMI policies can be very complex, depending on the policy's levels of educational and socio-economic development, national identity, socio-cultural history, local linguistic ecology, relationships between different ethnolinguistc groups and political stability. However, the push for more English, in line with its perceived significance by various interest groups including business communities and social elites, may persuade political leadership to pursue a more pro-English policy. In such cases, a compromise solution may require showing tolerant attitudes towards English in the private sector which is out of state control in a market economy while having protectionist policies in the public sector. The polity of Bangladesh is a good example of this where EMI draws a line between the public and private higher education. While the government maintains the post-independence nationalist and modernist policies and does not permit the exclusive use of EMI in state-funded (public) universities, private universities have been using English exclusively as a medium of instruction since their inception in the early 1990s. Although research on MOI has drawn on teachers' and students' perspectives (e.g., Ali, 2013; Cho, 2012; Costa \& Coleman, 2012; Doiz, Lasagabaster \& Sierra, 2011), there has not been much work that shows how national MOI policies may provide the context for LPP actors to construct identities of languages and institutions.

So, it is required to analyze the current situation of English Medium Instruction (EMI) as it is largely related to the MOI policy of higher education in Bangladesh. That is why, this study aimed to address some of these concerns by critically examining the EMI policy within the context of Bangladeshi higher education.

\section{EMI Policy and Planning in Various Countries}

The $21^{\text {st }}$ Century has introduced many challenges in higher education. For this reason, there have been many recent studies of the medium of instruction of higher education around the world. EMI is the current trend that 
is being followed widely. Especially in Europe, many researchers have investigated the overall implementation of EMI by launching several large scale studies (Ammon and McConnell 2002; Maiworm and Wachter 2002; Wachter and Maiworm , 2008). In 2007, a study commissioned by the Academic Cooperation Association (ACA) investigated how many programmes were being taught in English in European universities. The study found (Wachter and Mairworm, 2008) that around 2400 courses were offered through English. The study also suggested that the majority of English medium programmes are postgraduate (Kirkpatrick, 2010). At the same time, the proportion of postgraduate students taking courses in English rises to $44 \%$ (Collins \& Halverson, 2009).

an overall success. Whilst there have been problems in the past, the advantages are presently numerous to the point where students now graduating can meet the global industry standards (Kim and Shon, 2009). Likewise, another two Asian countries Malaysia and Indonesia have been used EMI in higher education for some time, and many universities have developed international programs using EMI.

So, in Asia, the use of English is astounding; India houses one of the largest English-using populations in the world. English language is increasingly becoming recognized as part of education, as well as policy making in many nations in the region. The escalating use of English as well as the purposeful build up of educational institutions promising English, along with the language's firm grip on defining social elites in Bangladesh certainly asserts the language's overwhelming power. There are many attitudes associated with defining the power of language. Using a specific language, such as English in Bangladesh can determine what one thinks the language can provide for him or her, and likewise, what others can think of the individual when the language is used. English,
Like Europe, many Asian countries have been adopting English as a medium of instruction (Naun, 2003). However, unlike Europe, there is no large scale empirical study regarding the implementation of EMI in Asian countries. The few available studies (Altbach, 2004; Balla \& Penning, 1996) indicate that the formal colonized South Asian countries, such as India, Singapore, Malaysia and Hong Kong, have widely adopted EMI, while in other Asian countries, such as China, Japan and Korea, have also gained popularity for internationalization of higher education (Tsuneyoshi, 2005; Lassegard, 2006). Gradually, South Korea, Japan and China have updated its higher education introducing English as a medium of instruction. In Korea, EMI implementation has improved and has been the language that has been associated with power and prestige (due to its legacy from colonialism) has become the suitable vocabulary in society. Whereas in India English has become the primary language of communication and politics and thus, people have become comfortable with its usage. In the same way, this has now become the case concentrated only among Bangladeshi elites.

\section{Language Situation in Bangladesh}

Being one of the poorest nations in the world (see, Bolton, Graddol \& Meierkord, 2011), Bangladesh can neither prioritize research over other more pressing issues nor attract the language planning and policy (LPP) scholars and researchers from other countries. Thus, the polity remains underrepresented in international LPP scholarship. Nevertheless, there has been some work in the recent past that has provided an outline of the major issues and debates in languages and language policy (Banu \& Sussex, 2001; Hamid, 2006a, 2006b, 2009a, 2009b, 2011a; Hossain \& Tollefson, 2007; Imam, 2005; Mohsin, 2003; Musa, 1996; Rahman, 2007; Rahman, 2010; Thompson, 2007). Drawing on this body of 
work, a brief sociolinguistic overview of the Policy is presented in this section.

Bangla (aka Bengali) is the national language of Bangladesh which is spoken as a first language by 98 percent of the population. Although a monolingual national identity is highlighted in nationalist discourses, there are also a few dozen small languages spoken by a number of ethnic minority groups (Hamid, 2011a; Mohsin, 2003; Rahman, 2010). Urdu, the national language of Pakistan, is also part of the local linguistic ecology and is spoken by over 300,000 stranded Pakistanis.

English, the second language, which was brought to the sub-continent as part of British colonial rule, is seen as the language of power and social mobility (Erling, Hamid \& Seargeant, 2013). The British left India in 1947 leaving the colony divided into two independent countries based on religion: Pakistan which consisted of West and East Pakistan for Muslims and India for Hindus. Although united into one nation, the two parts of Pakistan were divided by different languages, cultures and over 1000 miles of hostile Indian territory.

In 1971, 24 years after the formation of Pakistan federation, East Pakistan broke away from Pakistan and emerged as an independent country. Bangla, the dominant language of East Pakistan, played a crucial role in the nationalist struggle leading to the national war of independence. A milestone in the journey of the Bangla-speaking people's nationalism was the Language Movement of 1952 at which several students from the University of Dhaka were killed by Pakistani police as they were protesting against the imposition of Urdu as the only state language of Pakistan. To Bangladeshis, Bangla became a symbol not only of national identity but also of their fight against exploitation and subjugation, and of the creation of an independent nation (Mohsin, 2003; Musa, 1996; Thompson, 2007).

\section{Language Policies in Post- Independence Bangladesh}

It is no surprise that the Bangla-based nationalism underpinned language and education policies in the new nation. Bangla was given the status of national language through the constitution of 1972 to be used in education, administration and the judiciary (Rahman, 1999). Even higher education in the country was to be delivered through Bangla replacing English, giving little attention to the practical questions of writing textbooks and other resources in the national language (Choudhury, 2001).

With the nationalistic euphoria gradually subsiding, education policy makers began to take note of the damage done to English teaching and learning as a consequence of nationalist policies (Hamid, 2009b). However, if earlier policies were extremist because of their neglect of English, latter policies were somewhat radical in promoting English, particularly when seen from the point of view of national resources (Hamid, 2009b). English was made a compulsory subject from Grade 1 in 1992 in the wake of a major educational reform which introduced a competency-based primary curriculum (Ahmed, 2005). Then, towards the end of the decade, English was introduced as a compulsory subject for first year undergraduate students in tertiary institutions across the country (Hamid, 2000).

However, while access to English was widened through one set of policies, there were other policies that at the same time promoted Bangla. For instance, the "Bengali Introduction Law" of 1987 made it clear that "Bengali was to be used in all spheres and at all levels for government purposes" (Banu \& Sussex 2001, p. 126), which was seen to have an impact on English proficiency development. It can be argued, therefore, that the government tried to maintain a balance between English and Bangla in national policies to ensure that promotion of English 
did not mean demotion of the national language (Hamid, 2009b).

\section{METHOD}

International University of Business, Agriculture and Technology (IUBAT) is one of the pioneer institutions among private universities in Bangladesh. IUBAT started offering academic programs in 1992 in affiliation with its partner, Assumption University of Bangkok, Thailand. Since its establishment, it has grown steadily, and currently IUBAT has over ten thousand students and 160 full-time staff members. It offers academic programs leading to nine professional bachelor degrees (e.g., Bachelor of Science in Agriculture and Bachelor of Science in Nursing), two diplomas and an MBA (Master of Business Administration) degree. Like all other private universities, IUBAT has been using English as a medium of instruction since its establishment. Its academic standards are recognized by the Bangladesh Public Service Commission, the apex body for recruiting public servants. It is a member of the London-based Association of Commonwealth Universities (ACU) and its degrees are recognized in 35 countries of the Commonwealth.

Seventeen academics and thirty-seven undergraduate students representing all six academic departments including Business, Agriculture, Engineering and Economics participated in the study. The teachers had varying lengths of teaching experience: five of them had taught for 6-8 years, six for 3-5 years and the remaining six teachers for $1-2$ years. Their academic qualifications also varied. Seven teachers had Masters/PhD degrees from English-speaking countries abroad. Three of them lived in an Englishspeaking country for a substantial period of time. However, the majority of them had qualifications from public universities in Bangladesh.
The student participants were selected from the six departments and were at different stages of their studies. Nine of them had been studying for more than three years at IUBAT. Around half of them were in the second semester whereas the remainders were in the fourth semester. In order to protect the identity of the students and teachers and the privacy of their views, they are identified as $\mathrm{T}$ or $\mathrm{S}$ followed by a number.

The study is followed a case study design that allows for investigating a contemporary phenomenon within its real-life context in which the boundaries between the phenomenon and the context are not clearly evident (Yin, 2003). The case study approach has been used to gain an in-depth understanding of teachers' and students' beliefs about the potential and actual situation of EMI in a specific context. This qualitative case study is an intensive, holistic and indepth analysis of a single phenomenon (Merriam, 1998; Patton, 2002). It is particularistic, descriptive and heuristic (Yin, 2003) and aimed at giving voice to a particular group of participants.

Within the case study design, we used semi-structured interviews and classroom observations to collect data. In the present article we mainly draw on teacher and student interviews. Each participant was interviewed individually for half an hour to 45 minutes in Bangla. All interviews were audiotape recorded, transcribed verbatim and translated into English by the authors. The transcriptions were sent back to the interviewees for verification.

The interview data were analyzed using qualitative content analysis (Corbin \& Strauss, 2008; Dörnyei, 2007; Flick, 2006). Following an inductive approach, we read the data repeatedly to identity major themes. Three themes were identified related to: implementation of EMI policy, choice and preference of EMI policy, educational 
effective of EMI policy, and these are discussed in detail in this section.

\section{FINDINGS AND DISCUSSION}

The interview data demonstrates that language uses at IUBAT, both inside and outside the classroom was dominated by English. Academic activities are carried out mainly in English:

Teachers and students use English in the class to discuss our courses for presentation, conversation and interview. (S12)

The dominance of English has forced Bangla to a peripheral existence, particularly for academic activities:

In my university teachers and students use mostly English to communicate with one another but sometimes faculties use Bangla to make the lesson more understandable for students but not frequently. (S13)

The hegemony of English is actualized in several ways. The first is the policy of the institution which is informed by the policy of higher education in the private sector at large:

As English is an international language and [the] medium of instruction [is] English in almost all private universities, this university has also chosen English. (T3)

In the previous extract $\mathrm{T} 3$ justified the choice of English as EMI by referring to the policy of private universities in the first place, but more importantly, to the status of English in the world at large. This reference to the global identity of English was recurrent in the data:

Because English is the international language in the world, the best way to communicate with different kinds of people is by learning English language. (T2)
Teachers' and students' language practices at IUBAT reproduced the hegemony of English, legitimizing its global identity which is seen to be the best means of communication across peoples. Reliance on English for academic purposes was also driven by logistic factors. For instance, the majority of the teachers referred to the availability of textbooks and other teaching and learning resources as being only available in English:

Most of the books in higher education are written in English. That is why, I use English so that the students can find similarities between what is written in the book and in the instruction. (T7)

The absence of textbooks in Bangla militated against the policy of introducing Bangla as MOI immediately after independence (Choudhury, 2001) and this is a problem which seems to have deteriorated over the past four decades (see Hamid, 2006a).

EMI practices were also informed by teachers' and students' beliefs about the value of EMI in developing students' language proficiency. T11 stated that his/her EMI practice aimed to improve students' speaking proficiency; S20 noted that "English medium can help us improve our listening, speaking and writing skill in English"; S32 observed that his/her "English proficiency has improved after taking EMI course"; and S5 noted:

Before taking EMI courses, I had no confidence in talking to/communicating with another person. But after taking EMI courses my English proficiency has improved.

Although confidence was found to entail the "chicken or egg" problem in Ali's (2013) research with EMI students in a Malaysian university - students not being able to articulate confidently whether their problem 
was low confidence or low level of proficiency-S5 suggests a specific relationship that attests to the positive effects of EMI.

\section{Choice and preference of EMI policy}

In spite of the domination of English in teachers' and students' language practices as well as the prospective of EMI in developing English proficiency, the majority of students admitted that they faced problems in EMI classes:

Yes, I am facing lots of problems because of the lack of vocabulary. (S34)

Yes, sometimes I have faced problems because my background is Bangla [medium] and I am not very good in English. (S4)

Given their low levels of proficiency in English, the majority of students observed that Bangla medium instruction would have been more helpful:

Yes, I think so. Because Bangla is our mother tongue, it is much easier than English. (S27)

Yes, I think it would be much easier to understand the subject matter if the course were taught in Bangla [in which] I can easily identify everything. (S24)

Students also admitted that they used Bangla materials, whenever available, to develop their understanding of difficult concepts. As S23 explained:

[...] some of the subjects are very hard to understand. So, we follow Bangla writers [...]

it would be much easier to understand the subject matter if the course were taught in Bangla.

Despite this acknowledgement of the value of learning in Bangla, some students were more attracted to the power of English:
Because Bangla is our mother tongue, undoubtedly Bangla is always preferable to us. It makes things more understandable. But English as an international language is more effective for us. So there are 50-50 choices for this. (S22)

The "50-50" conclusion does not follow from the evidence S22 presents. Bangla is "preferable" not just because it is his/her "mother tongue", but also because it helps to understand the content of the subject. S22 neither names similar benefits for English, nor explains why or how English was "more effective". Thus, it can be argued that the students were driven by the assumed benefits of English, although inexplicable, at the expense of the experiential and explicable benefits of Bangla. Further evidence is provided by S14 who has a correct understanding of the 50-50 rule, but is evidently biased towards English:

I am not sure about that. Sometimes it is easier when we are taught in English. Sometimes Bangla helps us to understand some matter clearly. But overall I think we should be taught in English. (S14)

Some other students argued that following a dual medium (Bangla and English) would be more appropriate. A typical view is represented by $\mathrm{S} 4$ :

Yes, I think classroom instruction should follow a dual medium at my university. I think it will be very helpful for every student.

However, a bilingual solution is least likely to be sought given that the whole sector has adopted English only and that the majority of students have internalized the invisible power of English:

When I consider the broad prospective of using English as a medium of communication, I think this is what we need most in the class. But, sometimes I cannot 
ignore the usefulness of Bangla given that the number of Bangla background students is very high and they do not have enough communication skills in English. (S3)

Thus, English is seen as the default choice while Bangla is expected to be given a peripheral role. This view becomes clearer when we look at their beliefs about English and Bangla.

\section{Educational effectiveness of EMI policy}

To understand teachers' and students' perception about the effectiveness of EMI, when asked about their beliefs of using English as a medium of instruction, The majority number of teachers gave their opinions by emphasizing students' English language skills and highlighted the present situation of English as well as job market demand. For instance, T6 refers to the role of English, "a commanding language", in grooming students and making them look "smart":

The students will be well groomed and smart in their practical life. In my opinion English is a commanding language. The benefit is the student learned a commanding language. (T6)

Similarly, T10 asserts that it is English which will help students stand out and be different from their non-proficient friends:

Yes, finally they like it because when they can speak in English they see that they are different from their friends and it is essential for their career.

The majority of the students held similar views of English and its value and felt that higher education should be in English:

No, I think our course in English is better than in Bangla [...] higher education [is] better in English. (S22)
Reconstruction of English as a valued language does not mean that the teachers and students ignored Bangla. In fact, almost all students asserted that they loved their "mother tongue". As T11 typically observed:

Bangla is our mother tongue; I especially love my mother tongue. Bangla is our first language. But it is not wrong to take English as our second language since the world is moving towards English. (T11)

In this article, the study has examined the implementation of EMI policy, choice and preference of EMI policy, and educational effectiveness of EMI policy in one private university in Bangladesh. Drawing on interview data, it has been illustrated how their language practices and beliefs, which are informed by EMI policies of the private sector higher education and macro-level MOI policies in the country. Under the influence of essentialist views, the beliefs and observations of teachers and students found in this study enrich the understanding of EMI policy at higher education.

Based on teachers' and students' views, it has been illustrated how language practices and ideologies may essentially perpetuate a linguistic hierarchy. Importantly, although the students experienced the value of Bangla in academic learning, they yet unattained power of English in their future imagined communities denied the potential of Bangla and rendered it unfit for higher education that aimed to produce graduates for the job market in a globalizing world. Notably, it appears that EMI in this specific context may end up producing "English-coated graduates" with a shallow foundation of content knowledge. This is evidenced by the views expressed by T14, although these went against the norms of self- and other-representation:

In private universities, they care more about language and dress than about knowledge. Again students in private universities are 
weak in subject matter. That is why, universities try to make their students marketable in this way. On the other hand, public universities' main focus is to make their students sound in the subject area.

The reproduction of private-public duality is notable in the extract. More notably, the "cloak of language" is only superficial and unreliable. The majority of students in private universities come from Bangla medium schooling with inadequate competence in English (Mahmud \& Gazi, 2012). Despite the policy prescription of using English only on campus and the provision of English language courses, the large majority of students may end up with "cosmetic" learning of English (Mohanty, Panda \& Pal, 2010). Thus, many of them may incur a double loss - the language as well as the content-with the promises of English remaining ever illusive.

The findings of this study reaffirm that the implementation of EMI policy at the private Universities of Bangladesh is an inevitable process that is likely to continue well into the future. Thus, the present study identified various problems; there is no question for the implementation, but rather how to effectively implement EMI at higher education institutions, how EMI can be maximized to meet policy objectives, and how to reduce EMI's side effects.

\section{CONCLUSION}

The results reported in this study confirms that the practice and choice of EMI policy at the private Universities of Bangladesh require to fulfill the present demand of English in local and international market. All teachers and students believed that English is the prime concerned for future career. The practice and choice of EMI enhances the creditability of this issue.

In addition, with regard to the educational effectiveness and difficulties, the result indicated that participants have conflicting views on the EMI's effectiveness regarding students' understanding of course content and on whether EMI classes actually improve students' English proficiency. But they generally support the EMI policy thinking their future career within the global world. In this respect, further replication studies at yet more Universities in different institutional settings would be desirable and could provide sound data that may be utilized to design an effective implementation strategy for EMI policy. After all, promoting a policy like EMI, which will have a deep educational and administrative impact, without any empirical evidence puts students at difficulty.

The number of private universities in Bangladesh has grown dramatically since the introduction of the University Act in 1992, and more such universities are in the pipeline. However, research on languages or MOI in higher education is almost non-existent. We invite researchers to investigate the higher education sector in the country to verify the conclusions that we have drawn in the present study drawing on larger samples of students, teachers and other stakeholders and multiple methods of data collection. Working with students and teachers in public universities and/or drawing on cohorts from both sets of universities could be particularly revealing.

Finally, the implementation of EMI policy has an issue of great debate not only in Bangladesh but in Asia and in Europe as well. How the EMI policy being effective by reducing the difficulties of teaching and learning in different linguistic, cultural, and social backgrounds plays out is likely to emerge as a big educational issue in future comparative studies of higher education. Considerably, this paper provides an analysis of the EMI policy at an institution in Bangladesh, which can provide as a point of reference for future studies. 


\section{Endnotes}

1. See Ali (2013, this issue) for Malaysia's somewhat different response to comparable global-local dilemma.

2. The University Grants Commission is the highest regulatory body of the government to monitor the operation of higher education institutions in public and private sectors.

\section{REFERENCES}

Ahmed, M. (2005). Teaching English in the primary school: Challenges and options Bangladesh Education Journal, 4(1), pp. 17-23.

Ali, L. H. (2013). Language policy and planning in Malaysia: Managing Englishmedium instruction at tertiary level. Unpublished $\mathrm{PhD}$ dissertation, The University of Queensland, Brisbane, Australia.

Ali, L. H. (2013). A changing paradigm in language planning: English-medium instruction policy at tertiary level in Malaysia. Current Issues in Language Planning, 14(1), pp. 73-92.

Ammon, U. \& McConnell, G. (2002). English as an academic language in Europe: $A$ survey of its use in teaching (Duisburger Arbeiten zur Sprach-und Kulturwissenschaft 48). Bern: Peter Lang.

Altbach, P. (2004). Globalization and the university: Myths and realities in an unequal world. Tertiary Education and Management, 10, pp. 3-25. Retrieved 16 January, 2013 from: http://ww.nhnea.org/assets/img/PubAlma nac/ALM_05_06.pdf

Balla, J., \& Penning, M. C. (1996). The perception of English-medium instruction by Tertiary-level Vocational Student in Hong Kong. retrieved 05March, 2013 from:

http://sunzil.lib.hku.hk/hkjo/view/33/3300 606.pdf.

Banu, R., \& Sussex, R. (2001). English in Bangladesh after independence:
Dynamics of policy and practice. In B. Moore (Ed.), Who's centric now? The present state of post-colonial Englishes (pp. 122-147). Melbourne: Oxford University Press.

Bolton, K., Graddol, D., \& Meierkord, C. (2011). Towards developmental world Englishes. World Englishes, 30(4), pp. 459-480.

Cho, D. W. (2012). English-medium instruction in the university context of Korea: Trade off between teaching outcomes and media-initiated university ranking. The Journal of Asia TEFL, 9(4), pp. 135-163.

Choudhury, S. I. (2001). Rethinking the two Englishes. In Alam, F. Zaman, N. \& Ahmed, T. (Eds.), Revisioning English in Bangladesh (pp. 15-25). Dhaka: University Press.

Collins, A. \& Halverson, R. (2009) Rethinking education in the age of technology, New York: Teachers College Press.

Corbin, J., \& Strauss, A. (2008). Basics of qualitative research: Techniques and procedures for developing grounded theory (3rd ed.). Thousand Oaks, CA: Sage.

Costa, F., \& Coleman, J. A. (2013). A survey of English-medium instruction in Italian higher education. International Journal of Bilingual Education and Bilingualism, 16(1), pp. 3-19. doi: 10.1080/13670050.2012.676621

Doiz, A., Lasagabaster, D., \& Sierra, J. M. (2011). Internationalisation, multilingualism and English-medium instruction. World Englishes, 30(3), pp. 345-359.

Dörnyei, Z. (2007). Research methods in applied linguistics: Quantitative, qualitative, and mixed methodologies. Oxford, NY: Oxford University Press. Erling, E. J., Hamid, M. O., \& Seargeant, P. (In Press). Grassroots attitudes to the positioning of English as a language for 
international development. In Erling, E.J. \& Seargeant, P. (Eds.), English and international development. Clevedon: Multilingual Matters.

Flick, U. (2006). An introduction to qualitative research. London: Sage.

Kirkpatrick, A. (2010) English as a lingua franca in ASEAN: A multilingual model. Hong Kong: Hong Kong University Press.

Hamid, M. O. (2000). A proposed contentbased academic purposes syllabus for the Foundation Course-2 at the University of Dhaka, Bangladesh. Unpublished MA dissertation, Deakin University, Melbourne.

Hamid, M. O. (2006a). English teachers' choice of language for publication: Qualitative insights from Bangladesh. Current Issues in Language Planning, 7(1), pp. 126-140.

Hamid, M. O. (2006b). An Apology for content-based instruction. Spectrum: Journal of the Department of English, 4, pp. 80-96.

Hamid, M. O. (2009a). Sociology of language learning: Social biographies and school English achievement in rural Bangladesh. Unpublished $\mathrm{PhD}$ dissertation, The University of Queensland, Brisbane, Australia

Hamid, M. O. (2009a). National planning of European languages in Bangladesh.

Dhaka University Studies, 66(1), pp. 5764.

Hamid, M. O. (2011a). Planning for failure: English and language policy and planning in Bangladesh. In Fishman, J.A. \& Garcia, O. (Eds.), Handbook of language and ethnic identity: The success-failure continuum in language and ethnic identity efforts (Vol. 2, pp. 192-203). New York:

Oxford University Press.

Hamid, M. O. (2011b). Socio-economic characteristics and English language achievement in rural Bangladesh.
Bangladesh e-Journal of Sociology, 8(20), pp. 31-50.

Hossain, T., \& Tollefson, J. W. (2007). Language policy in education in Bangladesh. In Tsui, A.B.M. \& Tollefson, J.W. (Eds.), Language policy, culture, and identity in Asian contexts (pp. 241257). Mahwah, NJ: Lawrence Erlbaum.

Imam, S. R. (2005). English as a global language and the question of nationbuilding education in Bangladesh. Comparative Education, 41(4), pp. 471486.

Kim, S. K. \& Shon, S.Y., (2009). Expert system to evaluate English medium instruction in Korean Universities. International Journal of Expert Systems with Applications, 36(9), pp. 1162611632.

Lin, A. M. Y., \& Martin, P. W. (2005). From a critical deconstruction paradigm to a critical construction paradigm: An introduction to decolonisation, globalisation and language-in-education policy and practice. In Lin, A.M.Y. \& Martin, P.W. (Eds.), Decolonisation, globalisation: Language-in-education policy and practice (pp. 1-9). Clevedon; Buffalo; Toronto: Multilingual Matters.

Lassegard, J. P. (2006). International student quality and Japanese higher education reform. Journal of Studies in International Education, 10(2), pp. 119140.

Mahmud, K., \& Gazi, M. G. H. (2012). Reading habits of the students with Bengali medium background at the English medium private universities in Bangladesh. Higher Education Studies, 2(2), pp. 100-106. doi: 10.5539/hes.v2n2p100

Maiworm, F., \& Wachter, B. (2002). EnglishLanguage-taught degree programmes in European Higher Education: Trends and success factors. Bonn: Lemmens. 
Merriam, S.B. (1998). Qualitative research and case study applications in education. San Francisco: Jossey-Bass Publishers.

Mohanty, A., Panda, M., \& Pal, R. (2010). Language policy in education and classroom practices in India. In Menken, K. \& Garcia, O. (Eds.), Negotiating language policies in schools: Educators as policymakers (pp. 211-231). New York; London: Routledge.

Mohsin, A. (2003). Language, identity, and the state in Bangladesh. In Brown, M.E., \& Ganguly, S. (Eds.), Fighting words: Language policy and ethnic relations in Asia (pp. 81-103). Cambridge, MA: MIT Press.

Musa, M. (1996). Politics of language planning in Pakistan and the birth of a new state. International Journal of the Sociology of Language, 118(1), pp. 6380.

Naun, D. (2003). The impact of English as a global language on educational politicies and practices in the Asia-pacific region. TESOL Quarterly, 37(4), pp. 589-613.

Patton, M. Q. (2002). Qualitative research and evaluation methods (3rd ed.). Thousand Oaks, CA: Sage.

Pennycook, A. (1994). Cultural politics of English as an international language. London: Longman.

Pennycook, A. (1998). English and the discourses of colonialism. London; New York: Routledge.

Rahman, A. M. M. H. (1999). English language teaching in Bangladesh: Didactics on the pragmatics of a language teaching policy. In Hunter, T. (Ed.), Collected papers of the international conference on national and regional issues in English language teaching: International perspectives (pp. 5-32). Dhaka: British Council.

Rahman, A. (2007). The history and policy of English education in Bangladesh. In Choi, Y.H. \& Spolsky, B. (Eds.), English education in Asia: History and policies (pp. 67-93). Seoul: Asia TEFL.

Rahman, T.(2010). A multilingual language in education policy for indigenous minorities in Bangladesh: Challenges and possibilities. Current Issues in Language Planning, 11(4), pp. 341-359.

Rassool, N. (2007). Global issues in language, education and development: Perspectives from post-colonial countries. Clevedon: Multilingual Matters.

Thompson, H. R. (2007). Bangladesh. In Simpson, A. (Ed.), Language and national identity in Asia (pp. 33-54). Oxford: Oxford University Press.

Tsuneyoshi, R. (2005). Internationalization strategies in Japan. Journal of Research in International Education, 4(1), pp. 6586.

Tsui, A. B.M. \& Tollefson, J. W. (2007). Language policy and the construction of national cultural identity. In Language policy, culture and identity in asian contexts. Edited by Amy B.M. Tsui and James W. Tollefson. Mahwah, NJ: Lawrence Erlbaum, pp. 1-21.

Wachter, B., \& Maiworm, F. (2008). Englishtaught programmes in European higher education. ACA. Papers on International Cooperation in Education. Bonn: Lemmens.

Yin, R. K. (2003). Case study research: Design and methods (3rd ed.). Thousand Oaks, CA: Sage. 